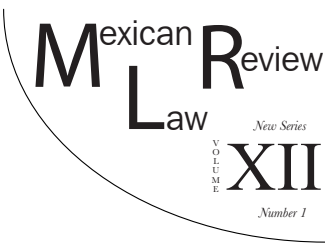

\title{
MEXICO'S RATIFICATION OF ILO CONVENTION NUMBER 98 AND THE FUTURE OF PROTECTION CONTRACTS
}

\author{
Stanley GACEK ${ }^{*}$
}

\begin{abstract}
This note reviewes and analyzes the impacts of Mexico's September 2018 ratification of International Labour Organization (ILO) Convention 98 on the right to organize and collective bargaining. Specifically, it focuses on what Mexico's ratification of the instrument means for the future of the protection contract system in terms of international law. Mexico's ratification of Convention 98 closes the doctrinal gap on protection contracts which was left by Convention 87, on freedom of association. Although Convention 98 does not cover the armed forces, the police, and public servants employed in state administration, according to international law, its ratification should invalidate much of the Mexican protection contract regime. Convention 98 is not selfenforcing, but ratification of the instrument subjects Mexico to the full scrutiny of the ILO's supervisory system regarding compliance with norms. Moreover, Mexico's domestic jurisprudence governing compliance with ratified international human rights treaties bodes well for effective judicial enforcement of the convention. With the ratification of Conventions 87 and 98, international law mandates the implementation of an authentically democratic labor relations system in Mexico. With the additional ratifications of Convention 29 on forced labor, Convention 100 on equal remuneration, Convention 105 on the abolition of forced labor, Convention 111 on discrimination in employment and occupation, Convention 138 on the minimum age for work, and Convention 182 on the worst forms of child labor, Mexico is bound by international law to comply with all globally recognized core labor standards.
\end{abstract}

KEYWORDS: ILO; collective bargaining agreements; protection contracts; Mexico.

* Senior Advisor for Global Strategies, United Food and Commercial Workers International Union (UFCW), Washington, D.C. since September of 2016; Deputy Director and Interim Director, ILO Office in Brazil, from August of 2011 to August of 2016; Member of the District of Columbia Bar Association since 1979; J.D., Harvard Law School, 1978; B.A., Harvard College, 1974; Visiting Instructor, Sociology Department, Harvard University, 2008. 
Esta revista forma parte del acervo de la Biblioteca Jurídica Virtual del Instituto de Investigaciones Jurídicas de la UNAM

Resumen: Esta nota revisa y analiza la ratificación de México del Convenio 98 de la OIT sobre organización y negociación colectiva que tuvo lugar en septiembre de 2018. Se enfoca especificamente en lo que significa la ratificación del instrumento por parte de México en términos de derecho internacional para el futuro de los contratos de protección. La ratificación del Convenio 98 cierra la brecha doctrinal sobre los contratos de protección dejada por el Convenio 87 sobre la libertad sindical. Si bien el Convenio 98 excluye de su cobertura a las fuerzas armadas, la policía y los funcionarios públicos empleados en la administración del Estado, su ratificación debería invalidar una gran parte del régimen de los contratos de protección con el derecho internacional. El Convenio 98 no se aplica por sí solo, pero la ratificación del instrumento somete a México al control completo del sistema de supervisión de la OIT en relación con el cumplimiento de la norma. Además, la jurisprudencia nacional de México que rige el cumplimiento de los tratados internacionales de derechos humanos ratificados es un buen augurio para la aplicación judicial efectiva de la convención. Con la ratificación de ambos Convenios 87 y 98, el derecho internacional ordena la implementación de un sistema de relaciones laborales mexicano auténticamente democrático. $Y$ con las ratificaciones adicionales del Convenio 29 sobre trabajo forzoso, el Convenio 100 sobre igualdad de remuneración, el Convenio 105 sobre la abolición del trabajo forzoso, el Convenio 111 sobre la discriminación en el empleo y la ocupación, el Convenio 138 sobre la edad mínima para trabajar y el Convenio 182 sobre las peores formas de trabajo infantil, México está obligado por el derecho internacional a cumplir con todas las normas laborales fundamentales reconocidas mundialmente.

Palabras Clave: OIT; acuerdos colectivos de negociación; contratos de protección, México.

Table of Contents

I. INTRODUCTION

II. The Doctrinal GaP Closed by Mexico's Ratification of ILO Convention 98

III. Workers Excluded From Coverage under

ILO Conventions 87 and 98 163

IV. What does Ratification of ILO Convention No. 98 Actually Mean in Terms of Legal Obligations? 165

\section{INTRODUCTION}

In September of 2018, the Mexican Senate unanimously ratified International Labour Organization (ILO) Convention Number 98, ${ }^{1}$ which guarantees work-

\footnotetext{
1 Convention No. 98 - Right to Organize and Collective Bargaining (1949), available at
} 
ers the right to organize, as well as the right to voluntary and authentic collective bargaining. ${ }^{2}$ This note examines what Mexico's ratification of the convention means for the future of Mexico's protection contract system in terms of international law.

For many years the rights of Mexican workers to organize trade unions of their own choosing as well as democratically negotiate their own Collective Bargaining Agreements (CBAs) have been limited and repressed. For example, it has been common for employers to sign CBAs with unions without the consent or knowledge of their employees. In many cases, these agreements have been signed prior to a business commencing operations, even before the hiring of the workforce. Such CBAs are known as "employer protection contracts," and "the unions that profit from them by selling 'protection' to employers are called 'protection unions."."3

Protection contracts are registered with Local or Federal Conciliation and Arbitration Boards (CABs), and it is believed that they make up the overwhelming majority of collective agreements in Mexico. ${ }^{4}$

\section{The Doctrinal GAP Glosed by Mexico’s Ratification of ILO Convention 98}

Mexico ratified ILO Convention 87, guaranteeing freedom of association for workers and employers, on April 1, 1950. ${ }^{5}$ The instrument was never renounced and has been in force in the country ever since its ratification nearly 69 years ago. ${ }^{6}$ Convention 87 was signed by the ILO's International Labor Conference (ILG) in $1948 .^{7}$

ILO Convention 98 is a fundamental instrument complementing freedom of association, with an explicit reference to collective bargaining. Convention 98 was adopted by the ILC in 1949 for the purpose of filling the normative

NORMLEX, International System on International Labour Standards, ILO, http://wrere.ilo. org/dyn/normlex.

2 OIT se congratula por ratificación del Convenio 98 en el Senado, EL UnIVERSAL, available at http:// wrerceleluniversal.com.mx/nacion/sociedad/oit-se-congratula.

3 Maquila Solidarity Network, Labour Justice Reform In Mexico - A Briefing PaPER (2017)

4 María Xelhuantzi López, La democracia pendiente: La Libertad de asociación sindiCal y los contratos de protección en MéXico, 167 (Sindicato de Telefonistas de la República Mexicana, 2000).

5 Ratifications for Mexico, NORMLEX - Information System on International Labour Standards, ILO, available at http://wrerr.ilo.org.dyn/normlex.

6 Ibid.

7 Convention No. 87 - Freedom of Association and Protection of the Right to Organize, 1948, NORMLEX- Information System on International Labour Standards, ILO, available at http://wrere.ilo.org/dyn/normlex. 
gaps in international labor law regarding the full scope of trade union rights: freedom of association, union organizing and collective bargaining. As Mexican labor lawyer Arturo Alcalde Justiniani has aptly noted, "Both date from seven decades ago; however, our government only ratified 87. Regarding 98, the Senate had suspended its ratification based on corporatist interests and with the intention of maintaining the practice of employer protection contracts being signed behind the workers' backs.". 8

A close examination of both ILO instruments supports Alcalde's suggestion of a possible doctrinal gap regarding Mexico's protection contract regime prior to the ratification of Convention 98. Convention 87 makes no reference per se to collective bargaining or to collective agreements. The principal focus of Convention 87 is the protection of the autonomy and independence of workers' and employers' organizations from state interference and repression. Articles 2, 3, 4, 7 and 10 of Convention 87 are quite clear in this regard. ${ }^{9}$ As the ILO Committee of Experts on the Application of Conventions and Recommendations (CEACR) has observed, "The principal objective of Convention No. 87 is to protect the autonomy and Independence of workers' and employers' organizations in relation to the public authorities, both in their establishment and in their functioning and dissolution." 10

Regarding this key objective of the Convention, the supervisory bodies of the ILO have granted admissibility to complaints alleging acts of omission on the part of the public authorities in relation to trade union rights. In other words, laws and practices on the part of ILO State Members which permit employer interference with or repression of trade union organization have been cognizable under Convention 87 and its principles. ${ }^{11}$

8 Maria del Pilar Martinez and Octavio Amador, Convenio 98 de la OIT sobre negociación colectiva requiere debate amplio: analistas, EL ECONOMISTA, available at http://wrere.eleconomista.com.mx/ gestion/Convenio-98-requiere-debate-amplio-analistas-20180912-0023.html (Free translation).

9 Convention No. 87 - Freedom of Association and Protection of the Right to Organize, 1948, NORMLEX - Information System on International Labour Standards, ILO, available at wwer.ilo.org/dyn/normlex.

10 General Survey on the fundamental Conventions concerning rights at work in light of the ILO Declaration on Social Justice for a Fair Globalization, Report of the Committee of Experts on the Application of Conventions and Recommendations, delivered to the International Labour Conference, $101^{\text {st }}$ Session, Geneva, ILO Document, 19 (2012).

11 See, for example, ILO Committee on Freedom of Association, Complaint against the United States, Case No. 1523, Report No. 284 (1992), NORMLEX - Information System on International Labour Standards, ILO, available at http://wwrw.ilo.org/dyn/normlex. Even though the United States has not ratified Conventions 87 and 98, all member states of the ILO are still subject to the review of the ILO Committee on Freedom of Association (CFA) in relation to both conventions, regardless of ratification. This practice does not apply to the other ILO supervisory bodies with jurisdiction over international labor standards, such as the CEACR and the Governing Body. 
In addition to protecting the exercise of trade union rights from state interference, Convention 87 has provided the singular implicit protection of the right to strike in the universe of ILO standards. As a matter of fact, there is no ILO convention which explicitly protects the right to strike. As the CEACR has noted:

In the absence of an express provision in Convention No. 87, it was mainly on the basis of Article 3 of the Convention, which sets out the right of workers' organizations to organize their activities and to formulate their programmes, and Article 10, under which the objectives of these organizations is to further and defend the interests of workers, that a number of principles relating to the right to strike were progressively developed (as was the case for other provisions of the Convention) by the Committee of Freedom of Association as a specialized tripartite body (as of 1952), and by the Committee of Experts (as of 1959, and essentially taking into consideration the principles established by the Committee on Freedom of Association). This position of the supervisory bodies in favour of the recognition and protection of the right to strike has, however, been subject to a number of criticisms from the Employers' group in the Committee on the Application of Standards of the International Labour Conference. ${ }^{12}$

The CEACR has stated that Convention 98 was adopted in 1949 "to supplement certain aspects of Convention No. 87" (emphasis mine) ${ }^{13}$ and with three main objectives:

(i) protection against acts of anti-union discrimination both at the time of taking up employment and in the course of employment, including the termination of the employment relationship; (ii) protection against acts of interference in the internal affairs of workers' and employers' organizations; and (iii) the promotion of collective bargaining. ${ }^{14}$

In terms of international labor law, Mexico's ratification of Convention 98 appears to close all the doctrinal loopholes regarding the protection contract system. In addition to Article 4 of the Convention, which promotes voluntary and authentic collective bargaining, Article 2 states:

1. Workers' and employers' organisations shall enjoy adequate protection against any acts of interference by each other or each other's agents or members in their establishment, functioning or administration.

2. In particular, acts which are designed to promote the establishment of workers' organisations under the domination of employers or employers' organisations, or to support workers' organisations by financial or other means,

12 General Survey on the fundamental Conventions concerning rights at work in light of the ILO Declaration on Social Justice for a Fair Globalization, 2008, op. cit., 46.

13 Ibid. at 67.

14 Id. 
with the object of placing such organisations under the control of employers or employers' organisations, shall be deemed to constitute acts of interference within the meaning of this Article. ${ }^{15}$

The Mexican practice of implementing and registering CBAs without the affected workers having any knowledge, consent, or power of authorization, let alone involvement in the collective bargaining process, contravenes the principles of Article 4 of Convention 98. Moreover, Mexico's protection contract regime effectively fosters total employer interference and dominance, making any legitimate, authentic and independent collective expression of worker demands at the bargaining table impossible, in direct contravention of Article 2 of Convention 98.

Admittedly, even before Mexico's ratification of Convention 98 in September of 2018, the Mexican protection contract system was submitted for scrutiny and review by the ILO's supervisory system on standards, pursuant to Convention No. 87. In fact, the protection system was mentioned in the CEACR's Report on Conventions and Standards presented to the 107th International Labour Conference of the ILO in May and June of 2018. The CEACR reports on individual country cases involving the conventions which Member States have actually ratified, the organization stated the following regarding Mexico and Convention 87:

Recalling that the Committee has expressed concern on this matter for a number of years, and that it was highlighted in conclusions of the Committee on the Application of Standards in June 2015, the Committee once again requests the Government, in consultation with the social partners, to take the necessary practical and legislative measures to find solutions to the problems arising out of the issue of protection unions and protection contracts, including in relation to the registration of trade unions. Reiterating that ILO technical assistance remains available and expecting that the implementation of the constitutional reform will provide an opportunity to address these problems, the Committee requests the Government to provide information on any developments in this respect, as well as in relation to the proposed reform of the Federal Labor Law (LFT). ${ }^{16}$

In point of fact, the CEACR engaged in some doctrinal bootstrapping in its 2018 report, which reviewed the protection contract issue under Convention 87 . That is because the instrument does not explicitly mention collective bargaining. The key language in the observations of the GEACR regards

15 Convention No. 98, Right to Organize and Collective Bargaining, 1949, NORMLEX, International System on International Labour Standards, ILO, available at http://wererc.ilo.org/ dyn/normlex.

16 Observation (CEACR) - adopted 2017, published $107^{\text {th }}$ ILC Session (2018) - Freedom of Association and Protection of the Right to Organize Convention, 1948 (No. 87) - Mexico (Ratification: 1950), NORMLEX, International System on International Labour Standards, ILO, available at http://werere.ilo.org/dyn/normlex. 
"...the issue of protection unions and protection contracts, including in relation to the registration of trade unions" ${ }^{\prime 17}$ (emphasis added). Trade union registration practices and procedures have everything to do with the principal objective of Convention 87, as noted above: protecting the autonomy and independence of workers' and employers' organizations vis-à-vis public authorities.

\section{Workers EXcLuded From Coverage UNDER ILO CONVENTIONS 87 AND 98}

It should be pointed out that Conventions 87 and 98 exclude certain categories of workers from direct coverage and protection. Article 9, Paragraph 1 of Convention 87 states that "The extent to which the guarantees provided for in this Convention shall apply to the armed forces and the police shall be determined by national laws or regulations." 18

The justification for exempting the armed forces and the police from coverage under Convention 87 is "the responsibility of these two categories of workers for the external and internal security of the State." 19

Nevertheless, ILO jurisprudence strictly limits the scope of the aforementioned Article 9, Paragraph 1 exclusion. This is important in terms of the right to form trade unions and the right to freedom of association enjoyed by Mexico's security and public safety personnel. The ILO supervisory system on standards has concluded that said exclusion should not apply to the following workers: civilian personnel in the armed forces, fire service personnel, prison staff, customs and excise officials, civilian employees in the industrial establishments of the armed forces ${ }^{20}$ civilian employees in the intelligence services ${ }^{21}$ or security employees of the legislative authority. ${ }^{22}$ Moreover, the CEACR has stated the following:

17 Ibid.

18 Convention No. 87, Freedom of Association and Protection of the Right to Organize, 1948, NORMLEX, International System on International Labour Standards, ILO, available at http://wreweilo.org/dyn/normlex.

19 General Survey on the fundamental Conventions concerning rights at work in light of the ILO Declaration on Social Justice for a Fair Globalization, op. cit.,.25.

20 See, for example, Nigeria - CEACR Observation, 2011; and Turkey - CEACR Observation, 2010. NORMLEX, International System on International Labour Standards, ILO, available at http://wwweilo.org/dyn/normlex.

21 See, for example, Czech Republic - CEACR, direct request, 2011, NORMLEX, International System on International Labour Standards, ILO, available at http://werere.ilo.org/dyn/normlex.

22 See, for example, Cambodia - CEACR, direct request, 2011; and United Republic of Tanzania (Zanzibar) - CEACR, observation, 2011, NORMLEX, International System on International Labour Standards, ILO, available at http://wrwre.ilo.org/dyn/normlex. 
In practice, as it is not always easy to determine whether workers belong to the military or to the police, in view of the Committee, workers should be considered civilians in case of doubt. For example, it considers that workers in private security firms and members of the security services of civil aviation companies should be granted the right to establish organizations, in the same way as workers engaged in security printing services and members of the security or fire services of oil refineries, airports and seaports. ${ }^{23}$

ILO Convention 98, Article 5 also exempts the armed forces and the police, and Article 6 exempts "public servants engaged in the administration of the State." 24 The CEACR has made clear that the scope of the armed forces and police exclusion of Convention 87 also must be read narrowly in Convention 98:

In provisions similar to those contained in Convention No. 87, Convention No. 98 leaves it to national laws or regulations to determine whether its provisions apply to the armed forces and police (Article 5(1)). However, the Committee wishes to recall that civilian personnel in the armed forces enjoy the rights and privileges set out in the Convention and that, even though certain employees in the private or the public sector may carry a weapon in the course of their duties, but are not members of the police or the armed forces, they cannot automatically be excluded from the scope of the Convention. ${ }^{25}$

The CEACR has determined that the the application of Article 5 of Convention 98 must make a distinction "between, on the one hand, public servants who by their functions are directly employed in the administration of the State (for example, in some countries, civil servants in government ministries and other comparable bodies, and ancillary staff), who may be excluded from the scope of the Convention, and, on the other hand, all other persons employed by the government, by public enterprises or by autonomous public institutions, who should benefit from the guarantees provided for in the Convention."26

ILO Convention 151 on Labour Relations (Public Service), adopted in 1978, ${ }^{27}$ and Convention 154 on Collective Bargaining, adopted in 1981, ${ }^{28}$

23 General Survey on the fundamental Conventions concerning rights at work in light of the ILO Declaration on Social Fustice for a Fair Globalization, op. cit., 25.

24 Convention No. 98, Right to Organize and Collective Bargaining Convention, 1949, NORMLEX, International System on International Labour Standards, ILO, available at http:// wrew.ilo.org/dyn/normlex.

25 General Survey on the fundamental Conventions concerning rights at work in light of the ILO Declaration on Social Fustice and a Fair Globalization, op. cit., p. 69.

26 Ibid. at 69.

27 Convention No. 151, Labour Relations (Public Service), 1978 - Convention concerning Protection of the Right to Organise and Procedures for Determining Conditions of Employment in the Public Service, NORMLEX, International System on International Labour Standards, ILO, available at http://wrw.ilo.org/dyn/normlex.

28 Convention No. 154 - Collective Bargaining, 1981 - Convention concerning the Pro- 
effectively closed the gap created by Convention 98, Article 5. In terms of international law, the ratification of these instruments is designed to guarantee collective bargaining rights for public servants directly employed in the administration of the State. ${ }^{29}$ Mexico has not ratified either of these conventions as yet.

Nevertheless, with the ratification of Convention 98, the practice of protection contracts in most of the Mexican economy is now covered by international law and its obligations.

\section{What does Ratification of ILO Convention No. 98 Actually Mean in Terms of Legal Obligations?}

The ratification of an ILO convention means that the member state "accepts the convention as a legally binding instrument." 30 In other words, ratification creates the obligation, according to international law, that a country's legal system and practice be brought into conformity with the norm. Other ILO instruments, such as declarations and recommendations, are not ratified by member states, and therefore do not have the same binding effect. Once it has ratified a convention, a country is subject to the entire ILO supervisory system responsible for ensuring that the instrument is applied.

According to Brazilian jurist Luiz Eduardo Gunther, who has thoroughly has examined ILO normative jurisprudence and its application and significance for his own country, an ILO convention essentially is "a treaty-a law of multilateral caracter." 31 Once an ILO member state ratifies a convention, it binds itself to the full "obligation of the norm," 32 complying with all of the conditions stipulated in the standard.

Although international law dictates that ILO conventions have a binding effect on the member states that ratify them, there is an obvious challenge: international norms are not self-enforcing, for the most part. Even with the available supervisory machinery available to examine the application and performance of member states vis-à-vis international labor standards, the

motion of Collective Bargaining, NORMLEX, International System on International Labour Standards, ILO, available at http://wrwe.ilo.org/dyn/normlex.

29 See Stanley A. Gacek and Ana Virginia Moreira Gomes, A Garantia do Direito a Negociação Coletiva no Serviço Público pela Organização Internacional do Trabalho, in A Convenção No. 151 DA Oit Sobre o Direito de Sindicalização e Negociação na Administracão Pública 22,23 (Editora LTr ed., 2017).

30 How International Labour Standards Are Created, ILO, Geneva, available at http:// wrew.ilo.org/global/standards/introduction-to-internatinoal-labour-standards.

31 Luiz Eduardo Gunther, A OIT e o Direito do Trabalho no Brasil 50 (Jurua Editora ed., 2011). (Free translation).

32 Ibid. at 50 (Free translation). 
Esta revista forma parte del acervo de la Biblioteca Jurídica Virtual del Instituto de Investigaciones Jurídicas de la UNAM http://www.juridicas unam mx/

https://biblio.juridicas.unam.mx/bjv

https://revistas.juridicas.unam.mx/

DOI: http://dx.doi.org/10.22201/iij.24485306e.2019.2.13642

ILO has no effective sanctioning power of its own to ensure the compliance of countries with the conventions they have ratified. ${ }^{33}$

The issue of self-enforceability and the lack thereof certainly is not unique to the ILO, but applies to many international law systems, presenting a "Westphalian dilemma" that is especially notable in international human rights law. ${ }^{34}$ Concrete compliance with-and enforceability of-ratified ILO conventions depend in great part on how the ratifying member state prioritizes the norm in terms of domestic jurisprudence.

In this respect, recent developments in Mexican jurisprudence regarding human rights instruments may be helpful in assessing the real legal impact of Mexico's recent ratification of ILO Convention 98. One of the principal questions is whether ratified international human rights treaties "are located above federal laws but below the Federal Constitution," or whether such ratified instruments "must be considered at the level of the Constitution."35

Citing the Mexican Supreme Court's decision of September 20, 2013, regarding compliance with the judgment of the Inter-American Court of Human Rights in the Radilla Pacheco case, international human rights law expert Christina Cerna notes that "The Supreme Court, however, in its judgment, jettisoned the concept of 'hierarchy,' and by a majority of ten votes, decided that human rights are recognized as a whole as a kind of amalgam, whether they derive from the Constitution or from international treaties to which Mexico is a party." 36

In any case, it does not appear that the principles and content of ILO Convention 98 are in conflict with the Mexican Federal Constitution, as amended in 2017. Indeed, newly amended Article 123 requires genuine trade union representation of the workers and certainty in the signing, filing and registration of CBAs. ${ }^{37}$ Given the conformity of the international norm with the general language of the Mexican constitutional reform, as well as the binding nature of the instrument according to international law, there is no

33 For a full discussion of this point, see Stanley A. Gacek, A Declaração sobre Princípios e Direitos Fundamentais no Trabalho da OIT de 1998 Dezesseis Anos Depois - Seu Significado para a Liberdade Sindical e a Negociação Coletiva no Brasil e no Mundo/Comentários Adicionais a Debate Permanente, in A DeclaraÇão de 1998 da OIT Sobre Principios e Direitos Fundamentais no Trabalho 116 - 127 (Editora LTr, ed., 2014).

34 Ibid. at 119.

35 Christina M. Cerna, Status of Human Rights Treaties in Mexican Domestic Law, in ASIL (American Society of International Law) Insights, Vol. 20, ISSUE 4 (2016), available at http://wwrwasil.org/insights/volume/20/issue/4/status-human-rights-treateis-mexican-domestic-law.

36 Ibid. also citing Radilla Pacheco v. Mexico, Preliminary Objections, Merits, Reparations and Costs, Inter-Am Ct. H.R. (ser. C) No. 209 (Nov. 23, 2009).

37 See Labour Justice Reform in Mexico - A Briefing Paper, op. cit., citing Decree Announcing Reform and Additions to Articles 107 and 123 of the Political Constitution of the United States of Mexico, Diario Oficial de la Federación (February 24, 2017), available at http:// wrere.dof.gob. $m x /$ nota_detalle.php. 
reason why Mexico cannot and should not employ ratified Convention 98 to eliminate the protection contract system by means of all necessary enabling legislation, regulation and judicial action. In having ratified both Conventions 87 and 98, Mexico is required by international law to ensure a genuinely democratic labor relations system.

FInally, it is important to note that with the ratification of Convention 98 in 2018, Mexico has ratified all of the fundamental ILO conventions with regards to labor rights, including: the Forced Labour Convention 29 of 1930 (Mexican ratification in 1934); the Equal Remuneration Convention 100 of 1951 (Mexican ratification in 1952); the Abolition of Forced Labour Convention 105 of 1957 (Mexican ratification in 1959); the Discrimination (Employment and Occupation) Convention 111 of 1958 (Mexican ratification in 1961); the Minimum Age Convention 138 of 1973 (Mexican ratification in 2015); the Worst Forms of Child Labour Convention 182 of 1999 (Mexican ratification in 2000); as well as the Freedom of Association and Protection of the Right to Organize Convention 87 of 1948 (Mexican ratification in 1950). ${ }^{38}$

The norms mentioned above make up the core labor standards of the ILO, and Mexico should be commended for ratifying each and every one of them. This fact also means that Mexico is bound by international law to comply with all of the fundamental labor rights currently recognized by the global community.

38 Ratifications for Mexico, NORMLEX, Information System on International Labour Standards, ILO, available at http://wrere.ilo.org/dyn/normlex. 